\title{
Effects of Land Consolidation Period and Tillage of Hollowed Villages on Soil Properties in Loess Plateau
}

\author{
Wei-hua ZHANG ${ }^{1, a}$, Zeng-hui MA ${ }^{1, b, *}$ and Lu ZHANG ${ }^{1, c}$ \\ ${ }^{1}$ Shaanxi Provincial Land Engineering Construction Group CO., LTD.; Key Laboratory of Degraded and Unused Land \\ Consolidation Engineering, the Ministryof Land and Resources of China; Shaanxi Province Land Reclamation Engineering \\ Technology Research Center; Xi’an, China, 710075 \\ a zhangwh.sdj@foxmail.com, ${ }^{\mathrm{b}} 70061451 @ q q . c o m,{ }^{\mathrm{c}}$ luluqiaofeng@126.com \\ *Corresponding author
}

\begin{abstract}
The land consolidation in hollowed villages deeply affected soil properties in loess plateau. The object of this work was to analysis the soil properties changes in 6 consolidation years with 2 tillage types. Results showed that the soil bulk density, soil clay content, $\mathrm{pH}$, soil organic matters, total $\mathrm{N}$, Olsen $P$, available $K$ were increased during 6 years. Meanwhile, a higher soil bulk density, soil clay content, organic matters, total $\mathbf{N}$ were found in rotary tillage than in plough tillage. It is concluded that land consolidation of hollowed villages are could increase arable land and improve soil properties with the increase of consolidation years, furthermore, rotary tillage can accelerate this trend compared to plough tillage.
\end{abstract}

Keywords-land consolidation; hollowed villages; loess plateau; soil properties

\section{INTRODUCTION}

Hollowed villages have become increasingly aggravated due to the population outmigration and rural land recession in Loess plateau[1]. The hollowed villages and abandoned residential lands had resulted decreased arable land area and many environmental problems[2]. Land consolidation can increase arable land area, improve rural competitive productivity, and changes the ecological environment. However, it is also considered that land consolidation may resulted soil compaction[3], or the soil may be lack of organic matters or microorganism, and thus, caused land retirement or land degradation[4].

Academic sphere pays more attention to rural land consolidation, and mainly focused on the potential of hollowed village land consolidation, mechanism, and modes[6]. The land consolidation of hollowed village had become a method to promote domestic demand, promoting new countryside construction, and realize the urban-rural overall development. However, the soil properties after implementation of land consolidation had less studied. And the effects of different tillage types after consolidation also should be evaluated.

In the present work, six different consolidated period's villages with 2 tillage types were selected to evaluate the changes of soil properties after land consolidation. The purpose of this study was to provide a practical base for improvement of hollowed village land consolidation and soil foster after consolidation.

\section{MATERIALS AND METHODS}

\section{A. Experimental Design}

The study was carried out in Chengcheng County, Shaanxi, China. Where located in the southeastern of the loess plateau, $109^{\circ} 46^{\prime} 30^{\prime \prime}-110^{\circ} 05^{\prime} 50^{\prime \prime}$ E, 34 $55^{\circ} 45^{\prime}$ $35^{\circ} 27^{\prime} 05^{\prime \prime} \mathrm{N}, 407-1268 \mathrm{~m}$ asl. The site has a semiarid, continental, monsoon climate with a long-term mean annual temperature of $12^{\circ} \mathrm{C}$, annual precipitation of $680 \mathrm{~mm}$, frost period 204d.

\section{B. Tillage Types}

After land consolidation, the hollowed villages were mainly changed to arable land, using plough tillage (PT) or rotary tillage (RT) for agricultural production. Plough tillage is a traditional tillage method, harrowing the soil to the 20$\mathrm{cm}$ depth with one pass of a disc harrow and two passes of a cultivator followed by planking; Rotary tillage harrowing the soil to the $10-\mathrm{cm}$ depth twice with a rotary cultivator. The grown crops are maize and spring wheat, with one crop grown each year.

\section{Soil Samples Collecting}

We selected 6 different land consolidation periods villages, the consolidation year was from 2008 to 2013. Each village has two fields using RT and PT, respectively. Soil samples were collected in 2014 after the crops were harvested with a depth $0-20 \mathrm{~cm}$. Meanwhile, we selected two sites besides the consolidated land as control, where sampled from the mud wall.

The soil bulk density (BD) was measured using ringknife; the soil texture was measured by Mastersizer 2000 (Malvern, UK); pH was measured by $\mathrm{pH}$ meter. The soil organic matters (SOM) and total nitrogen (TN) were determined by the dry combustion $\left(450^{\circ} \mathrm{C}\right)$ method using a CHNS-analyzer (Elementar Vario El, Germany), Olsen phosphorus (OP) and available phosphorus (AK) were determined using the Olsen method. 


\section{Statistical Methods}

A SAS (Statistics Analysis System) package (SAS Institute, 1989) was used to conduct analyses of variance (ANOVA). Least significant differences (LSD) were used to detect mean differences between periods and tillage types.

\section{RESULTS}

\section{A. Soil Texture Changes after Land Consolidation}

Figure 1 showed that the soil texture were silt loam in both consolidated land and mud wall. With the increase of land consolidated periods, the soil texture turnout to be more clay and the averaged sand content increasing rate is $4.2 \%$ under PT and 7.3\% under RT. The sand contents were significantly different among 2008, 2009, 2010, and 2013 under both tillage types, while no significant differences were found between 2011 and 2012. The silt content and sand content were no significant differences among all the consolidated year under PT and RT.

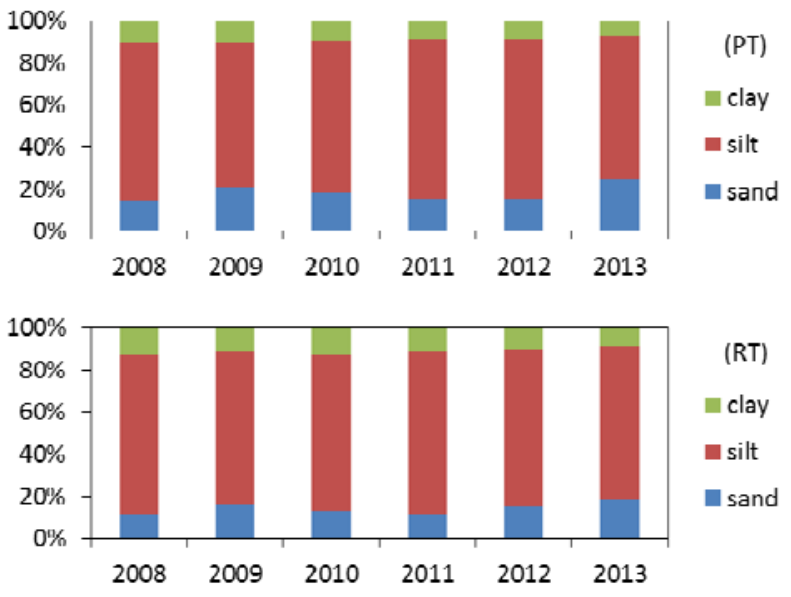

Figure 1. Soil texture of the consolidated land under PT and under RT in 2008-2013.

\section{B. Soil pH and Bulk Density Changes after Land Consolidation}

With the increase of land consolidation periods, the soil $\mathrm{pH}$ was increased with a logarithmic growth trends: $\mathrm{pH}=0.259 \ln (\mathrm{x})+7.303, \mathrm{R}^{2}=0.854$, where $\mathrm{x}=$ consolidation years. No significant differences between PT and RT. The average increase rate is $1.34 \%$.
TABLE I. SOIL PH IN DIFFERENT CONSOLIDATION YEAR UNDER PT AND RT.

\begin{tabular}{ccc}
\hline Consolidation year & PT & RT \\
\hline $2008^{\mathrm{a}}$ & $7.71 \pm 0.35 \mathrm{aA}$ & $7.76 \pm 0.42 \mathrm{aA}$ \\
2009 & $7.69 \pm 0.11 \mathrm{aA}$ & $7.68 \pm 0.38 \mathrm{aA}$ \\
2010 & $7.69 \pm 0.38 \mathrm{aA}$ & $7.71 \pm 0.61 \mathrm{aA}$ \\
2011 & $7.63 \pm 0.31 \mathrm{aA}$ & $7.62 \pm 0.37 \mathrm{aA}$ \\
2012 & $7.59 \pm 0.30 \mathrm{aA}$ & $7.43 \pm 0.46 \mathrm{aA}$ \\
2013 & $7.22 \pm 0.64 \mathrm{aA}$ & $7.29 \pm 0.55 \mathrm{aA}$ \\
\hline
\end{tabular}

a. Means followed by the same lowercase letter in a column in PT or RT are not significantly different according to Fisher's protected LSD test at the 0.05 probability level. Means followed by the same uppercase letter in a row in a given year are not significantly different according to Fisher's protected LSD test at the 0.05 probability level.

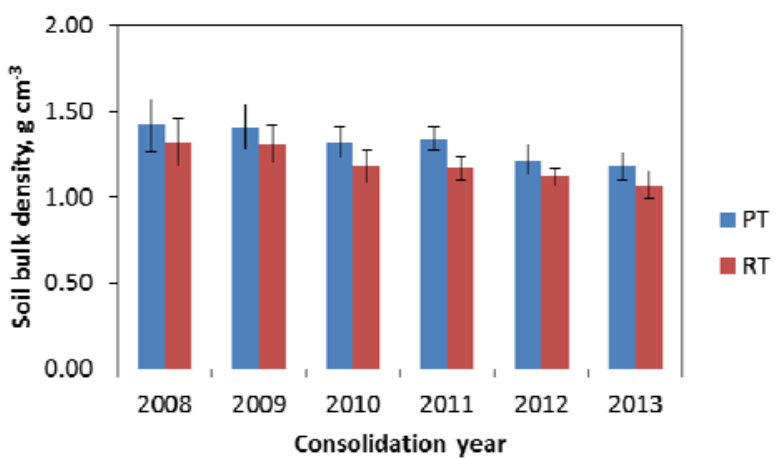

Figure 2. Soil bulk density after consolidation under PT and RT in 20082013.

Results showed that BD was increase with the increase of consolidation periods. After 6-years planting, BD was increased $23.4 \%$ under RT and increased 20.2\% under PT compared to 1-year planting, respectively. The RT treatment significantly decreased soil BD compared to PT with an average rate $9.97 \%$.

\section{Soil Nutrient Changes after Land Consolidation}

Table 2 showed that the soil nutrient changes after consolidation. The SOM was increased with the increase of consolidation periods. With 6-year consolidation, SOM increased 53\% and 213\% compared to 1-year consolidation under PT and RT, respectively. However, no significant differences were found between PT and RT after 6-year consolidation.

Total nitrogen was increased slightly with consolidation years under PT and RT. After 6-year consolidation, TN was increased from 0.88 to $1.06 \mathrm{~g} \mathrm{~kg}^{-1}$ under PT, while increased from 0.71 to $1.09 \mathrm{~g} \mathrm{~kg}^{-1}$ under RT.

Olsen-P was significantly different in 2008, 2009, 2012, and 2013 compared to 2010 and 2011 under PT. However, it was significantly increased with consolidation years under RT. It was 16\% larger in 2008 and 2009 compared to 2012 and 2013 under RT. No significant differences were found in 2010 and 2011 compared to other years.

Available phosphorus was not changed after consolidation under PT or RT in the 6 consolidation years. 
TABLE II. THE CHANGES OF SOM,.TN, OP, AND AK AFTER LAND CONSOLIDATION IN 2008-2013 UNDER PT AND RT.

\begin{tabular}{|c|c|c|c|c|c|}
\hline \multirow{2}{*}{ Tillage } & \multirow{2}{*}{ Year } & SOM & TN & OP & \\
\hline & & $\mathrm{g} \cdot \mathrm{kg}^{-1}$ & $\mathrm{~g} \cdot \mathrm{kg}^{-1}$ & $\mathrm{mg} \cdot \mathrm{kg}^{-1}$ & $\mathrm{mg} \cdot \mathrm{kg}^{-1}$ \\
\hline \multirow{6}{*}{$\begin{array}{l}\text { Plough } \\
\text { tillage }\end{array}$} & 2008 & $11.5 \pm 0.7 \mathrm{a}$ & $1.06 \pm 0.06 a$ & $11.5 \pm 0.33 a$ & $128.3 \pm 16.7 a$ \\
\hline & 2009 & $10.3 \pm 0.4 \mathrm{a}$ & $1.05 \pm 0.09 a$ & $10.9 \pm 0.98 a$ & $125.7 \pm 12.6 a$ \\
\hline & 2010 & $7.2 \pm 0.6 b$ & $0.93 \pm 0.08 \mathrm{ab}$ & $9.1 \pm 0.25 b$ & $116.9 \pm 11.6 a$ \\
\hline & 2011 & $7.4 \pm 0.3 b$ & $0.90 \pm 0.04 \mathrm{bc}$ & $9.5 \pm 0.37 b$ & $124.5 \pm 14.0 \mathrm{a}$ \\
\hline & 2012 & $6.5 \pm 0.2 b$ & $0.78 \pm 0.06 \mathrm{c}$ & $10.1 \pm 0.61 \mathrm{ab}$ & $120.0 \pm 15.7 a$ \\
\hline & 2013 & $7.5 \pm 0.6 b$ & $0.88 \pm 0.13 b c$ & $12.7 \pm 0.81 \mathrm{a}$ & $126.7 \pm 11.9 a$ \\
\hline \multirow{6}{*}{$\begin{array}{l}\text { Rotary } \\
\text { tillage }\end{array}$} & 2008 & $12.5 \pm 0.7 \mathrm{a}$ & $1.09 \pm 0.07 \mathrm{C}$ & $12.8 \pm 0.39 a$ & $148.0 \pm 13.2 \mathrm{a}$ \\
\hline & 2009 & $11.2 \pm 0.4 \mathrm{a}$ & $1.10 \pm 0.08 \mathrm{bc}$ & $12.5 \pm 0.32 \mathrm{a}$ & $154.2 \pm 13.3 a$ \\
\hline & 2010 & $8.1 \pm 0.5 b$ & $0.88 \pm 0.03 c$ & $11.7 \pm 0.23 \mathrm{ab}$ & $153.4 \pm 12.0 \mathrm{a}$ \\
\hline & 2011 & $8.7 \pm 0.2 b$ & $0.90 \pm 0.01 \mathrm{ab}$ & $11.6 \pm 0.25 \mathrm{ab}$ & $154.0 \pm 12.8 \mathrm{a}$ \\
\hline & 2012 & $8.8 \pm 0.2 b$ & $0.78 \pm 0.04 \mathrm{c}$ & $11.1 \pm 0.10 \mathrm{~b}$ & $147.9 \pm 9.7 a$ \\
\hline & 2013 & $4.0 \pm 0.2 \mathrm{c}$ & $0.71 \pm 0.01 \mathrm{a}$ & $11.0 \pm 0.12 b$ & $133.4 \pm 7.4 \mathrm{a}$ \\
\hline
\end{tabular}

a. Means followed by the same lowercase letter in a column are not significantly different according to Fisher's protected LSD test at the 0.05 probability level.

\section{DisCUSSION AND RESUlTS}

This paper showed that with the consolidation periods growth, the soil properties changed in consolidated land of the hollowed villages. The consolidation period is an important factor and tillage types also affected soil properties. The soil clay content and soil $\mathrm{pH}$ were increased both with logarithmic growth trends under two types of tillage. The increase of soil clay content enhanced the water capacity and decreased the infiltration rate. With the increase of consolidation period, SOM, TN, and OP were also increased. Furthermore, RT is better than PT especially in soil texture, BD and OP. Hollowed villages' consolidation could increase arable land area, with a suitable tillage type, and the soil quality could also be increased. The SOM increased largely under RT mainly due to the low content in 2013 with only $4.0 \mathrm{~g} \mathrm{~kg}^{-1}$.

Results showed that reclamation period less than 3 years, the soil nutrient would be fluctuating. While after 3 or 4 years planting, the soil nutrient of consolidated land will be increase significantly. Rotary tillage is better than plough tillage in Loess plateau.

It is also concluded that the soil quality of land consolidation of hollowed villages required further study.

\section{REFERENCES}

[1] Y.S. Liu, Y. Liu, Y.F. Chen, and H.L. Long, "The process and driving forces of rural hollowing in China under rapid urbanization,” J. Geographical Sciences, vol. 20, 2010, pp. 876-888, doi:10.1007/s11442-010-0817-2.

[2] H. L. Long, Y.R. Li, Y.S. Liu, M. Woodsd, J. Zou, “Accelerated restructuring in rural China fueled by 'increasing vs.decreasing balance' land-use policy for dealing with hollowed villages,”. Land Use Policy, vol. 29,2012, pp. 11-22, doi:10.1016/j.landusepol.2011.04.003

[3] Meng Huisheng, Wang Jing, Guo Jiankui, et al. Preliminary study on physical properties of soil compact in land consolidation in loess plateau[J]. Chinese Agricultural Science Bulletin, 2009, 25(24): 549552. (in Chinese with English abstract)

[4] Yang Jin, Liu Li, Sun Chuanmin, et al. Soil components and fertility improvement of added cultivated land[J]. Transactions of the Chinese Society of Agricultural Engineering (Transactions of the CSAE), 2008, 24(7): 102-105. (in Chinese with English abstract)

[5] Wei Xiuju, Hu Zhenqi, He Man. Potential problems of ecological environment resulted from land rehabilitation and their macroscopic management countermeasures[J]. Transactions of the Chinese Society of Agricultural Engineering (Transactions of the CSAE), 2005, 21(Supp.1):127-130. (in Chinese with English abstract)

[6] Liu Yansui, Zhang Fugang, Zhang Yingwen, 2009. Appraisal of typical rural development models during rapid urbanization in the eastern coastal region of China. Journal of Geographical Sciences, 19(5): 557-567. 